\title{
Activation and Regulation of B Cell Responses by Invariant Natural Killer T Cells
}

\author{
Derek G. Doherty *, Ashanty M. Melo, Ana Moreno-Olivera and \\ Andreas C. Solomos
}

Discipline of Immunology, Trinity Translational Medicine Institute, Trinity College Dublin, Dublin, Ireland

\section{OPEN ACCESS}

Edited by:

Luc Van Kaer,

Vanderbilt University,

United States

Reviewed by:

Mark L. Lang,

University of Oklahoma Health Sciences Center,

United States

Patricia Barral,

King's College London,

United Kingdom

*Correspondence:

Derek G. Doherty

derek.doherty@tcd.ie

Specialty section: This article was submitted

to T Cell Biology,

a section of the journal

Frontiers in Immunology

Received: 30 April 2018

Accepted: 31 May 2018

Published: 18 June 2018

Citation:

Doherty DG, Melo AM, MorenoOlivera A and Solomos AC (2018)

Activation and Regulation of

$B$ Cell Responses by Invariant Natural Killer T Cells.

Front. Immunol. 9:1360. doi: 10.3389/fimmu.2018.01360
CD1d-restricted invariant natural killer T (iNKT) cells play central roles in the activation and regulation of innate and adaptive immunity. Cytokine-mediated and CD1d-dependent interactions between iNKT cells and myeloid and lymphoid cells enable iNKT cells to contribute to the activation of multiple cell types, with important impacts on host immunity to infection and tumors and on the prevention of autoimmunity. Here, we review the mechanisms by which iNKT cells contribute to B cell maturation, antibody and cytokine production, and antigen presentation. Cognate interactions with B cells contribute to the rapid production of antibodies directed against conserved non-protein antigens resulting in rapid but short-lived innate humoral immunity. iNKT cells can also provide non-cognate help for the generation of antibodies directed against protein antigens, by promoting the activation of follicular helper $T$ cells, resulting in long-lasting adaptive humoral immunity and B cell memory. iNKT cells can also regulate humoral immunity by promoting the development of autoreactive B cells into regulatory B cells. Depletions and functional impairments of iNKT cells are found in patients with infectious, autoimmune and malignant diseases associated with altered B cell function and in murine models of these conditions. The adjuvant and regulatory activities that iNKT cells have for B cells makes them attractive therapeutic targets for these diseases.

Keywords: invariant natural killer T cells, B cells, antibodies, disease, CD1d, glycolipids

\section{INVARIANT NATURAL KILLER T (iNKT) CELLS CONTROL INNATE AND ADAPTIVE IMMUNE RESPONSES}

Invariant natural killer $\mathrm{T}$ cells are frequently considered a "bridge" between the innate and adaptive immune systems. They are classed as innate $\mathrm{T}$ cells because their $\mathrm{T}$ cell receptors (TCRs) are semiconserved and display specificity for conserved non-peptide antigens. They display effector-memory phenotypes and can respond immediately to infection or inflammation without the need for prior antigen priming. iNKT cells possess multiple effector functions, similar to those of conventional

\footnotetext{
Abbreviations: APC, antigen-presenting cell; APRIL, a proliferation-inducing ligand; BAFF, B cell activation factor; Bcl-6, B cell lymphoma-6; BCR, B cell receptor; CAR, chimeric antigen receptor; CLL, chronic lymphocytic leukemia; CVID, common variable immunodeficiency; Breg cell, regulatory B cell; DC, dendritic cell; $\alpha$-GalCer, $\alpha$-galactosylceramide; Ig, immunoglobulin; IL, interleukin; iNKT cell, invariant natural killer T cell; iNKT $_{\mathrm{FH}}$ cell, follicular helper invariant natural killer T cell; MDSC, myeloid-derived suppressor cell; MHC, major histocompatibility complex; NK cell, natural killer cell; PD-1, programmed death-1; SAP, signaling lymphocytic activation molecule-associated protein; SLE, systemic lupus erythematosus; TCR, $\mathrm{T}$ cell receptor; $\mathrm{T}_{\mathrm{FH}}$ cell, follicular helper $\mathrm{T}$ cell; $\mathrm{Th}$ cell, helper $\mathrm{T}$ cell; $\mathrm{T}_{\text {reg }}$ cell, regulatory $\mathrm{T}$ cell.
} 
T cells of the adaptive immune system, such as targeted granular release of cytolytic mediators and the release of T helper type 1 (Th1), Th2, Th17, and regulatory $\left(\mathrm{T}_{\text {reg }}\right)$ cytokines, allowing them to activate, polarize, and regulate adaptive immune responses. Ultimately, iNKT cell responses can dictate the outcomes of microbial infections, autoimmune diseases, and cancer, and for this reason, they are attractive potential targets for therapeutic intervention for multiple types of disease. However, iNKT cells are more than simply the conjoining cell type linking innate and adaptive immunity. They can stimulate and regulate multiple cell types at many levels and thereby are central controllers of innate and adaptive immune responses.

Invariant natural killer T cells, also known as type 1 NKT cells, are clonally expanded T cells expressing a TCR composed of an invariant $\alpha$-chain $(\mathrm{V} \alpha 24-\mathrm{J} \alpha 18$ in human and $\mathrm{V} \alpha 14-\mathrm{J} \alpha 18$ in mice) paired with a restricted set of $\beta$-chains, which displays specificity for glycolipid antigens presented by CD1d $(1,2)$. This $\mathrm{T}$ cell population is the best characterized member of a wider repertoire of CD1d-restricted T cells, mostly with undefined TCR specificities. CD1d-restricted T cells other than iNKT cells are collectively termed type 2 NKT cells $(3,4)$. The present review will focus mainly on type 1 NKT cells. Type 1 or iNKT cells express a number of stimulatory receptors that are frequently found on natural killer (NK) cells, such as NK1.1 in mice and NKG2C and NKG2D in humans. Their TCRs can recognize a number of self $(5,6)$ and microbial $(7,8)$ glycosphingolipids; however, most research on murine and human iNKT cells has utilized the prototypic glycolipid, $\alpha$-galactosylceramide ( $\alpha$-GalCer), which binds to CD1d and activates murine and human iNKT cells (9). Activation of iNKT cells with $\alpha$-GalCer in vitro results in target cell killing and the rapid release of multiple growth factors and cytokines $(1,2)$. iNKT cells are of particular interest because of their ability to produce cytokines associated with all of the $\mathrm{CD} 4^{+}$helper $\mathrm{T}(\mathrm{Th})$ cell lineages, including the Th1 cytokines interferon- $\gamma$ (IFN- $\gamma$ ) and tumor necrosis factor- $\alpha$ (TNF- $\alpha$ ), the Th 2 cytokines interleukin-4 (IL-4), IL-5, and IL-13, the Th9 cytokine IL-9, the Th17 cytokines IL-17A and IL-22, and the $\mathrm{T}_{\text {reg }}$ cytokine IL-10 (10, 11). These cytokines contribute to the activation and polarization of $\mathrm{CD}^{+}$and $\mathrm{CD}^{+} \mathrm{T}$ cells (12) and natural killer (NK) cells $(12,13)$. Cytokines and CD1d-dependent interactions between iNKT cells and dendritic cells (DCs) $(14,15)$, macrophages (16), neutrophils $(17,18)$, and myeloid-derived suppressor cells (MDSC) $(19,20)$ lead to the activation and regulation of the effector activities of these cells (Figure 1).

Invariant natural killer $\mathrm{T}$ cells make essential contributions to adaptive immune responses by promoting the maturation of dendritic cells into antigen-presenting cells (APCs). Physical interactions between activated iNKT cells and DC result in the expression of major histocompatibility complex (MHC) class II molecules, co-stimulatory molecules such as CD80 and CD86, and the release of IL-12 by the DC. This adjuvant effect involves CD1d/TCR, CD40/CD40L, and CD80/86/CD28 interactions between the two cells (21-24). iNKT cells also promote DC maturation in vivo: a single intravenous dose of $\alpha$-GalCer can stimulate the maturation of DCs into APCs, capable of activating $\mathrm{CD}^{+}$and $\mathrm{CD}^{+}{ }^{+} \mathrm{T}$ cells specific for a co-administered protein (25). iNKT cells prime DC to cross-prime $\mathrm{CD}^{+} \mathrm{T}$ cells $(15,26,27)$ and to promote $\mathrm{CD} 4^{+}$Th1 and Th 2 cell differentiation and activation $(14,28-30)$. A subset of iNKT cells can also kill DC (31).

Invariant natural killer T cells can also provide help for B cells. They can boost antibody responses by directly interacting with $\mathrm{B}$ cells presenting glycolipid antigens on CD1d (cognate B cell help) and indirectly by activating follicular helper $\mathrm{T}\left(\mathrm{T}_{\mathrm{FH}}\right)$ cells specific for protein antigens presented by B cells on MHC class II (non-cognate B cell help). This adjuvant activity makes iNKT cells and glycolipids attractive targets for boosting vaccine responses and preventing antibody-mediated diseases. iNKT cells also can regulate pathogenic $\mathrm{B}$ cell responses. Here, we review recent findings on the roles and mechanisms by which iNKT cells influence $B$ cell function and how they may contribute to the pathogenesis of and protection against diseases that involve aberrant B cell proliferation, maturation, or regulation.

\section{ACTIVATION OF B CELLS}

$B$ cells are uniquely able to recognize antigens that bind their surface immunoglobulin (Ig) receptors, resulting in the release of soluble antibody, which mediates the humoral immune response through pathogen neutralization, opsonization, and complement fixation. In the adaptive immune system, naïve antigen-specific lymphocytes are rarely activated by antigen alone. Naïve $\mathrm{T}$ cell activation requires an antigen-specific signal through the TCR and a co-stimulatory signal from a professional APC. Naïve B cell activation requires antigen recognition by the Ig receptor and additional signals that can come either from a $\mathrm{CD}^{+} \mathrm{T}$ cell (thymus-dependent) or, in some cases, directly from microbial components (thymus-independent). B cells and T cells sample antigens in secondary lymphoid tissues, the lymph nodes, and the spleen, which provide a microenvironment that is ideal for enabling physical interactions between $\mathrm{T}$ cells and $B$ cells and APCs, such as macrophages and DC. Lymph nodes receive antigens from the tissues via the lymphatics. Lymph nodes are divided into lobules, each consisting of an outer $\mathrm{B}$ cell-rich cortical region, a $\mathrm{T}$ cell-rich paracortical region, and an inner medulla (32). The B cells cluster together in lymphoid follicles. Upon antigenic stimulation, B cells proliferate and form germinal centers, where their Ig genes undergo somatic hypermutation and class switch recombination (33-37). The spleen receives antigens from the blood and consists of the white pulp embedded in red pulp. T cells and B cells accumulate in the white pulp, whereas erythrocytes dominate the red pulp. Murine spleen has an additional B cell-rich area, the marginal zone, between the white and red pulp, a region that is absent in human spleen (38).

Thymus-dependent B cell responses require the dual recognition of antigen by B cells and T cells. DC internalize protein antigens in the tissues and migrate via the lymphatics to the $\mathrm{T}$ cell-rich zones of lymph nodes. Here, they present antigenic peptides bound to MHC class II molecules to naïve T cells. T cell activation is associated with their differentiation into $\mathrm{T}_{\mathrm{FH}}$ cells, characterized by the expression of the B cell lymphoma-6 (Bcl-6) transcription factor, CD40 ligand, inducible T cell costimulator, the chemokine receptors CXCR4 and CXCR5, IL-21, programmed death-1 (PD-1), and signaling lymphocytic activation 


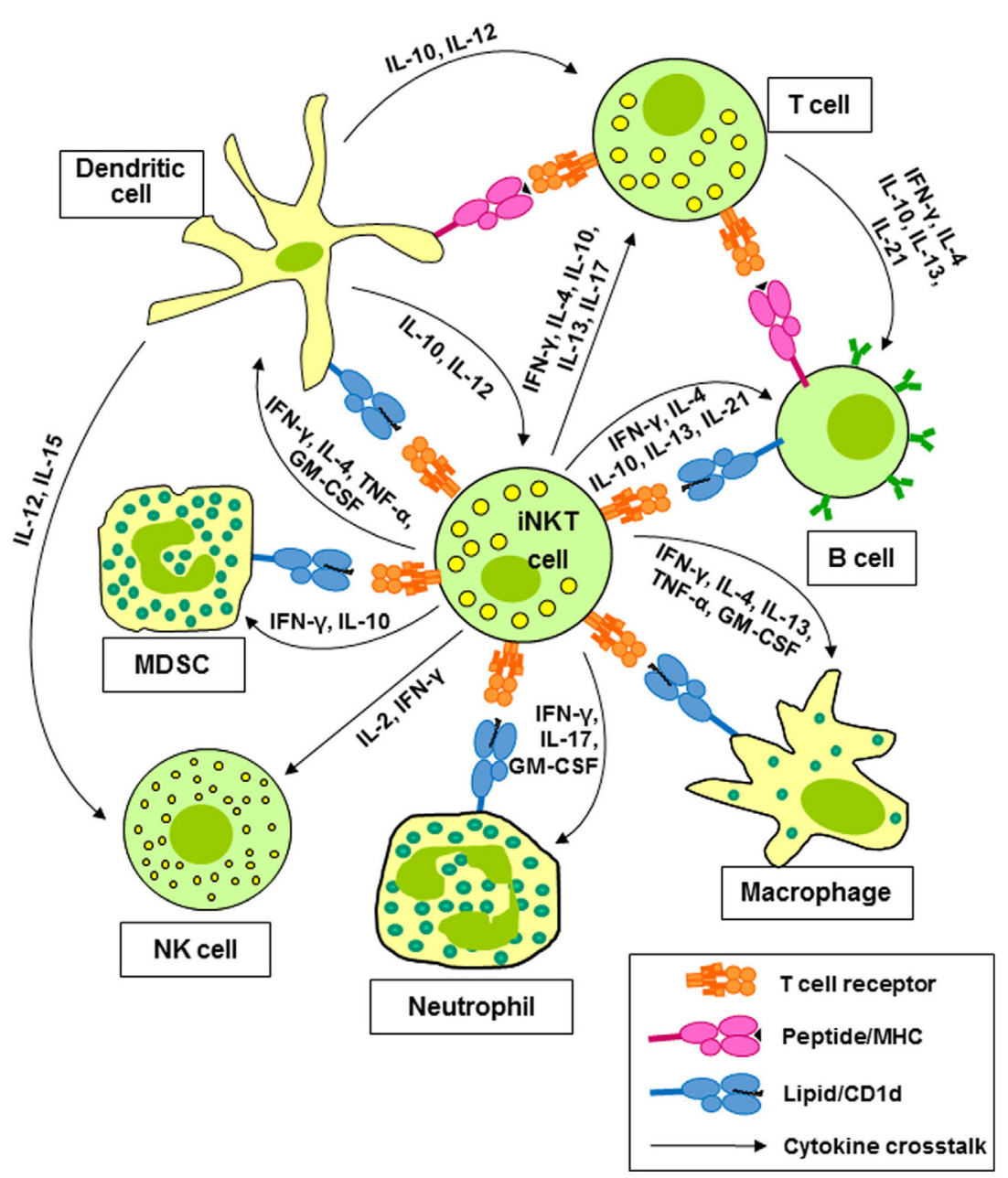

FIGURE 1 | Invariant natural killer T (iNKT) cells activate and regulate multiple cells of the innate and adaptive immune systems. Cytokines released by iNKT cells contribute to the activation and polarization of CD4+ and CD8 ${ }^{+} \mathrm{T}$ cells and natural killer (NK) cells. Cytokines and CD1d-dependent interactions between iNKT cells and dendritic cells (DCs), macrophages, neutrophils, and myeloid-derived suppressor cells (MDSC) lead to the activation and regulation of the effector activities of these cells.

molecule-associated protein (SAP) $(33,39)$. The $\mathrm{T}_{\mathrm{FH}}$ cells then relocate to the borders between the $\mathrm{T}$ and $\mathrm{B}$ cell areas, where they interact with antigen-specific B cells. In the lymph node follicles, the same antigen binds to a B cell receptor (BCR), resulting in internalization, processing, and cell-surface presentation on MHC class II molecules. The B cell migrates to the T-B borders, where it presents antigen to a $\mathrm{T}_{\mathrm{FH}}$ cells (34-36). Upon recognition of the peptide-MHC class II complex, the T cell expresses CD40 ligand, which ligates CD40 on the B cell, leading to B cell proliferation and differentiation. The $\mathrm{T}$ cell also secretes the cytokines IFN- $\gamma$, IL-4, IL-10, and IL-21, which are required for Ig isotype switching $(40,41)$. Cognate $\mathrm{T}$ cell-B cell interactions result in the proliferation of $\mathrm{B}$ cells in germinal centers, and somatic hypermutation, and affinity maturation of their Igs, resulting in the generation of long-lived antibody-secreting plasma cells and memory B cells (36). Cognate T-B cell interactions can also stimulate extrafollicular proliferation of $\mathrm{B}$ cells and their maturation into plasmablasts, which do not undergo affinity maturation and are short-lived. These B cells mediate transient innate-like responses (35).

Thymus-independent B cell responses are elicited by nonprotein antigens that do not stimulate $\mathrm{T}$ cells, such as bacterial polysaccharides and microbial toll-like-receptor ligands. These antigens are recognized by subsets of innate B cells, such as marginal zone B cells and B-1 cells, which do not reside in the follicles. Thymus-independent responses generally lead to rapid antibody responses to pathogens mediated by short-lived, lowaffinity extrafollicular plasma cells $(42,43)$.

\section{iNKT CELLS CAN PROVIDE NON- COGNATE B CELL HELP}

Invariant natural killer T cells can activate, regulate, enhance, and sustain humoral immune responses. In the steady state, iNKT cells are distributed throughout the spleen and lymph nodes. Upon 
activation, they consolidate in the marginal zones of the spleen and the interfollicular regions and medulla of the lymph nodes, where they can interact with APCs and T cells. Later, they are found in the germinal centers (44-48). Coadministration of $\alpha$-GalCer with immunizing antigen to mice results in enhanced production of antibodies specific for the antigen (49-51). This help provided by iNKT cells is non-cognate and does not require the expression of CD1d by B cells, but requires the co-expression of CD1d and MHC class II by DC and CD40 ligand expression by iNKT cells (52). Upon administration of $\alpha$-GalCer, iNKT cells residing in the marginal zones of the spleen are activated by $\mathrm{CD} 8 \alpha^{+} \mathrm{DC}$, resulting in reciprocal activation of the DC and their relocation to the borders between the $\mathrm{T}$ and $\mathrm{B}$ zones of the white pulp where they activate helper $\mathrm{T}$ cells specific for the co-administered antigen (Figure $2 \mathrm{~A}$ ). These $\mathrm{T}$ cells acquire $\mathrm{T}_{\mathrm{FH}}$ functions and provide help to cognate B cells $(45,46)$. The result is a typical thymus-dependent B cell response, with formation of germinal centers, antibody class switching and affinity maturation, and the induction of long-lived antibody-secreting plasma cells and memory B cells (Figure 2A) $(46,51,53,54)$. iNKT cellassociated $\mathrm{B}$ cell activation factor (BAFF) and a proliferationinducing ligand (APRIL) are required for long-term maintenance of the B cell responses (55). Non-cognate help from iNKT cells for the generation of alloreactive antibodies following hepatocyte transplantation in the absence of exogenous glycolipid administration has been demonstrated (56), suggesting that endogenous iNKT cell-activating glycolipids are present. In summary, noncognate B cell help by iNKT cells boosts adaptive immunity by promoting the generation of long-lived antibody responses and B cell memory.

\section{iNKT CELLS CAN PROVIDE COGNATE B CELL HELP}

Invariant natural killer $\mathrm{T}$ cells can also provide direct cognate help for B cells reactive against lipid-containing antigens internalized through the BCR (Figure 2B) $(57,58)$. This has been demonstrated using protein or hapten antigens that are physically linked to $\alpha$-GalCer, which were shown to be internalized by B cells, leading to presentation of $\alpha$-GalCer on CD1d molecules and resulting in the acquisition of $\mathrm{T}_{\mathrm{FH}}$ phenotypes by iNKT cells. This results in reciprocal activation of the $\mathrm{B}$ cells, leading to the formation of extrafollicular plasmablasts and germinal centers, affinity maturation, and the generation of robust protein- or hapten-specific immunoglobulin M (IgM) and IgG responses, but not long-lived memory cells $(59,60)$. Cognate B cell help provided by iNKT cells requires CD1d expression by B cells, CD40-CD40 ligand signaling, CD80-CD86 costimulation, and IFN- $\gamma$ but not IL- 4 . The iNKT cells acquire $\mathrm{T}_{\mathrm{FH}}$ phenotypes, including the expression of Bcl- 6 and their ability to provide cognate $\mathrm{B}$ cell help requires IL-21 (Figure 2B).

Cognate $\mathrm{B}$ cell help by $\mathrm{iNKT}_{\mathrm{FH}}$ cells that recognize environmental antigens occurs in nature. Mattner and co-workers (61) demonstrated that NKT cells can provide direct cognate help to B cells during infection of mice with Sphingomonas, a bacterium that carries iNKT cell agonist lipid antigens in its cell wall. Cognate recognition by iNKT cells of the tumor antigen, $N$-glycolyl-GM3, is also thought to contribute to the generation of specific antibodies, which are present in some people. This antigen binds to CD1d on human B cells and is presented to iNKT cells leading to iNKT cell activation, which may reciprocally drive antibody production by the B cells (62). Sphingolipids that accumulate in Gaucher's disease are recognized by murine and human type 2 NKT cells that express $\mathrm{T}_{\mathrm{FH}}$ phenotypes. Injection of mice with these lipids results in $\mathrm{NKT}_{\mathrm{FH}}$ cell expansion, induction of germinal center B cells, and the production of anti-sphingolipid antibodies. These lipids also activate human NKT cells which provide cognate help to B cells for antibody production in vitro (63). Stimulation of iNKT cells isolated from the pleural fluid of humans with tuberculosis with Mycobacterium tuberculosis antigens results in their expression of CXCR5, release of IL-21 and the provision of cognate B cell help for the production of IgG and IgA (64). Both $\mathrm{T}_{\mathrm{FH}}$ and iNKT $\mathrm{T}_{\mathrm{FH}}$ cells contribute to $\mathrm{B}$ cell help and the production of antibodies to Clostridium difficile toxin B in mice (65). Furthermore, CD1d expression by B cells was required for iNKT cell-mediated B cell help to a protein antigen in mice coimmunized with a mixture of the protein antigen and $\alpha$-GalCer, indicating that cognate iNKT cell-B cell interactions can play a role in the development of antibody responses to protein antigens (53). With some notable exceptions $(66,67)$, iNKT $_{\mathrm{FH}}$ cells appear to promote weaker antibody responses than conventional $\mathrm{T}_{\mathrm{FH}}$ cells, with smaller germinal centers and negligible differentiation of long-lived plasma cells and memory B cells $(59,60,68)$. Thus, cognate B cell help by iNKT cells boosts innate immunity by promoting the generation of robust, but short-lived, antibody responses to non-protein antigens.

Cognate iNKT cell help for B cell production of antibodies has also been demonstrated unequivocally in vitro using co-cultures of primary human B cells and fresh or expanded autologous iNKT cells. Human iNKT cells promote proliferation of autologous naïve and memory B cells and the subsequent production of $\operatorname{IgM}, \operatorname{IgG}$, and $\operatorname{IgA}$ in vitro by a mechanism that requires $B$ cell-iNKT cell contact and CD1d, but not $\alpha$-GalCer, suggesting that the iNKT cells recognize an autologous ligand (69-71). Surprisingly, antibody blocking experiments suggested that CD40-CD40 ligand interactions were not required for the provision of cognate B cell help by human iNKT cells. Humans have distinct subsets of iNKT cells, including $\mathrm{CD} 4^{+}$, $\mathrm{CD} 4^{-} \mathrm{CD} 8 \alpha^{-} \beta^{-}$(double-negative), and $\mathrm{CD} 8 \alpha^{+}$iNKT cells with distinct but overlapping functional activities (10-12). Separate analysis of the $\mathrm{B}$ cell helper activities of $\mathrm{CD} 4^{+}, \mathrm{CD} 8 \alpha^{+}$, and double-negative iNKT cells revealed that all subsets similarly induced $\mathrm{B}$ cell proliferation, but $\mathrm{CD} 4{ }^{+}$iNKT cells induced higher levels of antibody release $(69,71)$.

\section{iNKT CELLS INFLUENCE B CELL FUNCTIONS OTHER THAN ANTIBODY PRODUCTION}

In addition to their roles in antibody production, B cells influence $\mathrm{T}$ cell responses. B cells are potent APCs for T cells. They can prime $\mathrm{CD}^{+} \mathrm{T}$ cells without the requirement for $\mathrm{DC}$ or macrophages (72). Similar to T cells, B cells can produce Th1 and 


\section{A Non-cognate iNKT cell help}

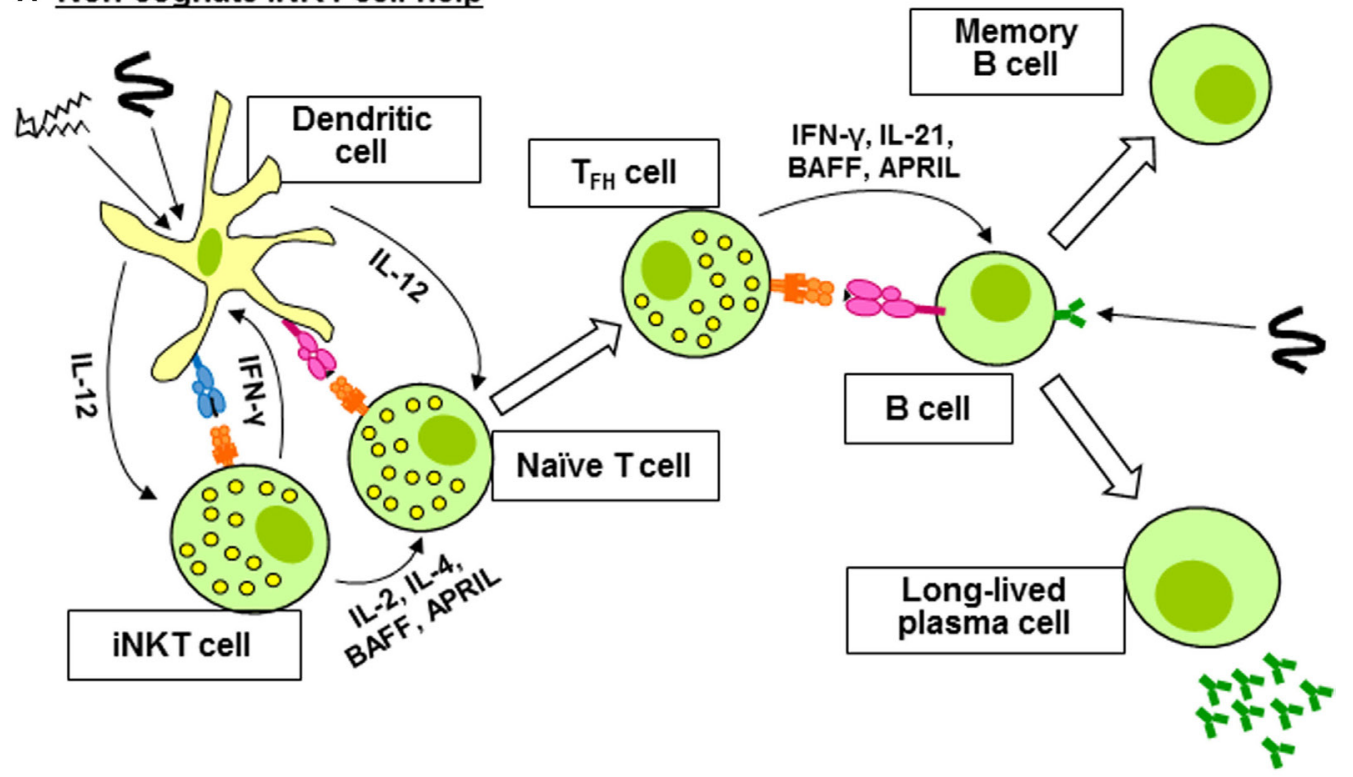

B Cognate iNKT cell help

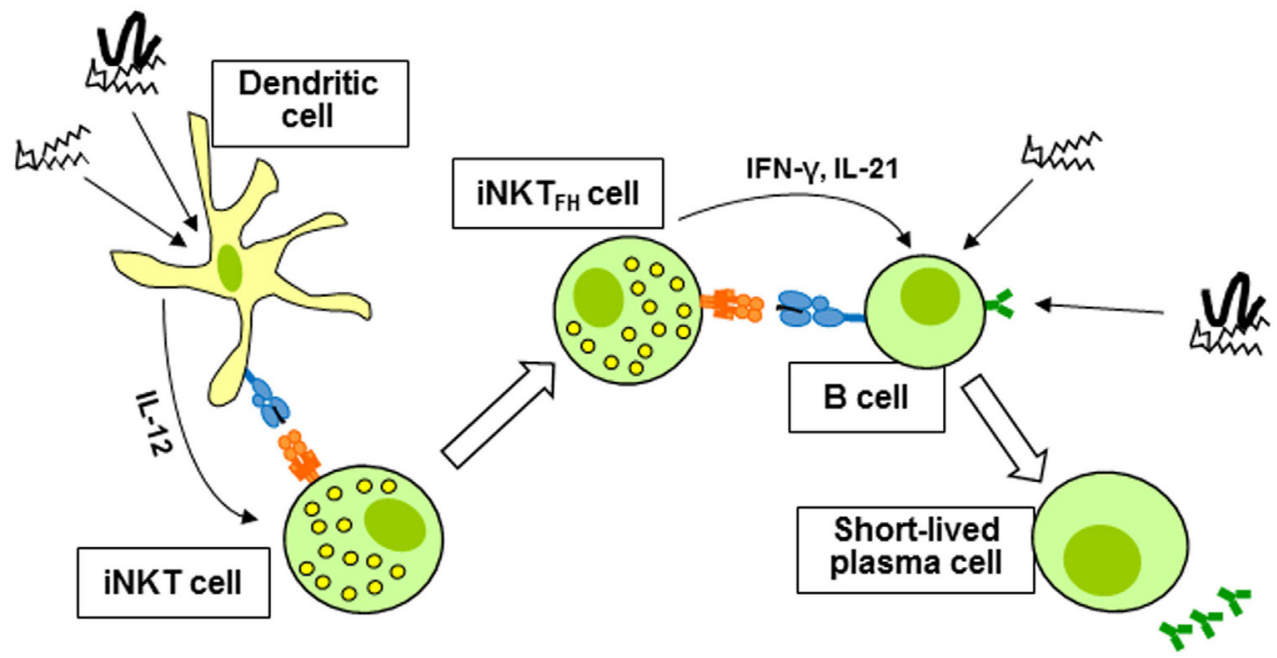

Immunoglobulin
$\longrightarrow$ T cell receptor

FIGURE 2 | Invariant natural killer T (iNKT) cells provide non-cognate and cognate help for antigen-specific B cells. (A) Coadministration of protein antigen and an iNKT cell ligand, such as $\alpha$-galactosylceramide (lipid antigen) results in internalization by a dendritic cell (DC) and simultaneous presentation of peptide fragments of the protein antigen on major histocompatibility complex (MHC) class II to a naive CD4+ $\mathrm{T}$ cell and of the lipid antigen on CD1d to iNKT cells. IFN- $\gamma$ production by the iNKT cell reciprocally promotes MHC class II antigen presentation and expression of CD40 by the DC, whereas IL-2, IL-4, B cell activation factor (BAFF), and a

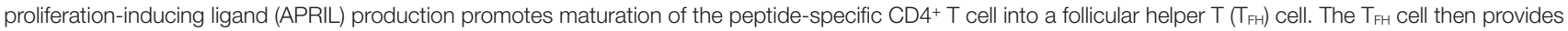
antigen-specific help for the proliferation of B cells in germinal centers, affinity maturation, antibody class switching, and the generation of long-lived antibodysecreting plasma cells and memory B cells. (B) iNKT cells recognizing lipid antigens presented by DC differentiate into follicular helper invariant natural killer T (iNKT $T_{F H}$ ) cells capable of activating B cells specific for lipid antigens or proteins or haptens conjugated to the lipid antigens. B cell activation is mediated by CD40

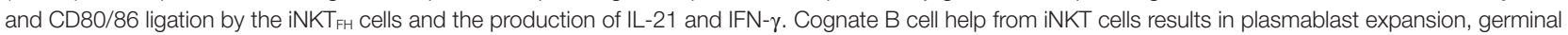
center formation, modest affinity maturation, and primary class switched antibody production. 
Th2 cytokines (73). Since iNKT cells are unique in that they can selectively secrete $\mathrm{Th} 1$, Th2, Th17, or $\mathrm{T}_{\text {reg }}$ cell cytokines $(10,11$, $16,74)$, it is possible that these cells may promote and/or regulate cytokine production, antigen presentation, and conventional $\mathrm{T}$ cell activation by B cells.

Our group was the first to show that cognate interactions between $\mathrm{CD}^{+}{ }^{+} \mathrm{iNKT}$ cells and $\mathrm{B}$ cells results in the differentiation of B cells into cells with phenotypes of regulatory B (Breg) cells in vitro (71). Breg cells are immunosuppressive cells that help maintain immunological tolerance via the production of IL-10, IL-35, and transforming growth factor- $\beta$ (75). Murine B cells expressing CD5 and high levels of CD1d (CD1d ${ }^{\text {hi }} C D 5^{+}$ $B$ cells), mainly marginal zone B cells, secrete IL-10 resulting in immunosuppression and protection against autoimmune disease $(76,77)$. In humans, a B cell population that produces IL-10 and inhibits Th1 cell responses is present in the CD $24^{\text {hi }} \mathrm{CD} 38^{\text {hi }} \mathrm{B}$ cell compartment, and this subset is functionally impaired in patients with systemic lupus erythematosus (SLE) $(78,79)$. We found that $\mathrm{CD} 4^{+}$human iNKT cells, but not $\mathrm{CD} 8 \alpha^{+}$or $\mathrm{DN}$ iNKT cells, induced the expansion of both $\mathrm{CD} 1 \mathrm{~d}^{\text {hi }} \mathrm{CD} 5^{+}$and $\mathrm{CD} 24^{\text {hi }} \mathrm{CD} 38^{\text {hi }}$ $\mathrm{B}$ cells in vitro by a mechanism that required cell-cell contact but not activation of the iNKT cells with $\alpha$-GalCer. Co-culturing $\mathrm{CD}^{+}{ }^{+}$iNKT cells with B cells also induced IL-4 and IL-10 production by the $\mathrm{B}$ cells and inhibited their ability to stimulate proliferation of alloreactive and antigen-specific conventional T cells (71). Cognate iNKT cell help by murine iNKT cells has also been shown to induce the expansion of IL-10-producing Breg cells in vivo, which was associated with a decrease in germinal center $\mathrm{B}$ cell and $\mathrm{T}_{\mathrm{FH}}$ cell expansion (80). These findings suggest that, as well as promoting antibody production by $\mathrm{B}$ cells, $\mathrm{CD}^{+}{ }^{+} \mathrm{iNKT}$ cells can induce the differentiation of B cells into immunosuppressive cells with impaired ability to present antigen to conventional T cells.

The roles of iNKT cells as promoters and regulators of B cell maturation and antibody responses have important implications for infectious and autoimmune diseases and cancers. In the following sections, we review recent research on the roles of iNKT cells in these classes of diseases, focusing particularly on infectious diseases where antibodies are required for protection, B cell lymphomas and leukemias, and B cell-mediated autoimmune diseases. Finally, we discuss the possible role and treatment potential of iNKT cells in immunodeficiencies that result in impaired or absent antibody responses.

\section{iNKT CELLS PROTECT AGAINST INFECTIOUS DISEASE}

Invariant natural killer $\mathrm{T}$ cells play a central role in the protection against infection. A number of bacterial glycolipids have been shown to bind to CD1d and stimulate iNKT cells $(7,8)$. Administration of $\alpha$-GalCer prior to pathogen challenge improved disease outcomes in experimental models of infection, including Plasmodium falciparum, Cryptococcus neoformans, Pseudomonas aeruginosa, and M. tuberculosis $(81,82)$. Mice lacking CD1d or iNKT cells suffered increase burdens of Borrelia burgdorferi, Streptococcus pneumonia, P. aeruginosa, M. tuberculosis, and Chlamydia pneumonia.
In murine models, CD1d and iNKT cells are required to generate protective antibody responses against several pathogens, including P. falciparum (83), S. pneumoniae (84), influenza virus $(85,86)$, herpes simplex virus (87), Bacillus anthracis (88), and Borrelia species (89). CD1d and iNKT cells are also needed for the production of IgE antibodies specific for allergens in experimental models of airway inflammation $(90,91)$ and for the generation of antibodies specific for allo- and xenoantigens in grafted mice (92). Thus, iNKT cells provide an adjuvant activity for the induction of antibody responses. These data suggest that exogenous stimulation of iNKT cells could be used to protect against infection, with glycolipid antigens serving as vaccine adjuvants.

\section{iNKT CELLS PROTECT AGAINST CANCER}

Invariant natural killer $\mathrm{T}$ cells are most notable for their roles in antitumor immunity. Mice with deletions in the CD1d or V $\alpha 14$ J $\alpha 18$ TCR genes, which lack iNKT cells, are predisposed to developing cancer and protection against cancer can be restored by adoptive transfer of iNKT cells (93). Furthermore, glycolipid activation of iNKT cells can both prevent and reverse tumor growth in mice $(9,94)$. iNKT cells can kill a number of human tumor cell lines in vitro, while their activation in vivo leads to downstream activation of natural killer $(\mathrm{NK})$ cells and $\mathrm{CD}^{+}$ T cells which infiltrate tumors $(95,96)$. iNKT cells are deficient and functionally impaired in most human cancers studied $(97,98)$. These observations have led to a number of clinical trials involving the adoptive transfer of $\alpha$-GalCer-pulsed autologous DC, ex vivo expanded iNKT cells, or both, in cancer patients (99, 100). Although these therapies stimulated antitumor immune responses in the patients, clinical efficacy has to date been limited.

Invariant natural killer $\mathrm{T}$ cells play important roles in B cell cancers. Chronic lymphocytic leukemia (CLL), the most common leukemia in adults, is characterized by the expansion of mature monoclonal $\mathrm{CD}^{+} \mathrm{B}$ cells (101). These cells can accumulate in the bone marrow and interfere with hematopoiesis, resulting in deficiencies of erythrocytes, platelets, lymphocytes, and antibodies. Since B cells express CD1d, they could potentially prime iNKT cells for cytolysis, one of the cardinal functions of iNKT cells. However, iNKT cells could alternatively provide B cell help for proliferation and antibody production. Recent studies (102-104) have found that circulating iNKT cells are depleted, but functionally active in patients with CLL. Reports are conflicting regarding whether CD1d expression by B cells is higher or lower in CLL patients compared to healthy controls (102, 103, 105-107). Our group provided evidence that downregulation of CD1d expression by CLL cells underlies the functional deficiency of iNKT cells in CLL patients, since the induction of CD1d expression by B cells using retinoic acid restored cytolytic killing of CLL cells by iNKT cells in vitro (104). iNKT cells are also depleted from the circulation of patients with multiple myeloma, a malignancy associated with the accumulation of transformed plasma cells in the bone marrow $(108,109)$. Myeloma cells express CD1d and are sensitive to lysis by NKT cells, but CD1d expression is downregulated during the progression of the disease 
and eventually lost altogether. iNKT cells are also depleted and functionally impaired in patients with non-Hodgkin's lymphoma (110) and human herpesvirus 8 multicentric Castleman disease, a virus-induced B cell lymphoproliferative disorder (111). Thus, it appears that iNKT cells play roles in B cell tumor immune surveillance but that these cells become suppressed or depleted during the course of the diseases.

\section{iNKT CELLS PROTECT AGAINST AUTOIMMUNE DISEASE}

Invariant natural killer $\mathrm{T}$ cells can also protect against autoimmune and metabolic diseases. Numerical and functional deficiencies of iNKT cells are found in patients with type 1 diabetes $(112,113)$ and in non-obese diabetic mice, a model of type 1 diabetes $(114,115)$. Adoptive transfer of iNKT cells from healthy mice protected non-obese diabetic mice from developing diabetes (116). iNKT cells are also depleted from the circulation of patients with multiple sclerosis and they expand in patients during remission $(117,118)$. They are deficient in mice that are predisposed to developing experimental autoimmune encephalomyelitis $(119,120)$, and these mice can be protected from developing encephalomyelitis by injection of $\alpha$-GalCer (121) or by overexpressing the V $\alpha 14 \mathrm{~J} \alpha 18$ TCR. Patients with SLE (122) and lupus-prone mouse strains (119) have reduced numbers of iNKT cells, suggesting that these cells may protect against lupus. B cell-mediated stimulation of iNKT cells is deficient in patients with SLE, suggesting that B cell defects underlie these iNKT cell deficiencies (123). However, iNKT cells may promote the development of lupus in some animal models. Recent studies have also implicated iNKT cells in obesity and metabolic diseases, including type 2 diabetes $(124,125)$.

Several lines of evidence suggest that iNKT cells and Breg cells can prevent the production of pathogenic autoantibodies, such as anti-double-stranded DNA IgG antibodies and rheumatoid factor, which are pathogenic in patients with SLE and rheumatoid arthritis, respectively, and in murine models of these diseases $(126,127)$. Inhibition of autoantibody production is mainly mediated by $\mathrm{CD}^{+}$marginal zone $\mathrm{B}$ cells, which express high levels of CD1d and produce IL-10 in a contact- and CD1d-dependent manner $(128,129)$. In contrast, iNKT cells can promote nonautoreactive antibody production by follicular B cells via the production of IL-17 and IL-21 (128-130). iNKT cells and CD1d also limit autoreactive $B$ cell activation and symptoms of disease in a model where circulating apoptotic cells trigger autoantibody production, resembling the situation in SLE patients (131). Thus, it appears that iNKT cells prevent autoimmunity in lupus-prone mice by inducing autoreactive B cells to differentiate into Breg cells. However, Shen and co-workers (132) showed that iNKT cells promote the production of anti-double-stranded DNA IgG in SLE patients and that expanded iNKT cells from SLE patients, but not healthy donors, induced the production of these autoantibodies by autologous B cells. Therefore, it appears that iNKT cells can either promote or prevent the production of antibodies by B cells and that this balance of activities may determine whether or not an individual develops SLE.

\section{iNKT CELLS AND ANTIBODY DEFICIENCIES}

Invariant natural killer $\mathrm{T}$ cells are also depleted and functionally altered in the circulation of patients with common variable immunodeficiency (CVID), a group of primary antibody deficiencies characterized by recurrent infections and susceptibility to autoimmunity, enteropathy, and lymphoid malignancy $(133,134)$. Patients with CVID display defects in B cell differentiation, resulting in accumulations of naïve and lessdifferentiated B cell populations and depletions of class switched memory B cells and plasmablasts $(135,136)$. This led Erazo-Borrás and co-workers (137) to investigate if the iNKT deficiency underlies the defect in B cell differentiation. They found that, although total iNKT cells were depleted, $\mathrm{iNKT}_{\mathrm{FH}}$ cells were expanded in the patients. However, $\alpha$-GalCer-pulsed iNKT cells were unable to induce autologous $B$ cell proliferation although they induced proliferation of healthy donor B cells. These findings suggest that iNKT cells are not impaired, but $B$ responsiveness to iNKT cells is impaired in patients with CVID. Indeed, lipid presentation by B cells is required for the maintenance of iNKT cells (123), suggesting that the defects in B cell differentiation in patients with CVID may lead to the depletions in iNKT cells observed.

\section{CONCLUDING REMARKS}

Innate recognition of self and microbial glycolipids enables iNKT cells to drive both cellular and humoral immune responses. Cellular immune responses, as exemplified in antitumor immunity, are mediated in part by the ability of iNKT cells and DC to reciprocally activate each other, resulting in the licensing of DC to activate conventional $\mathrm{T}$ cells and NK cells. Similar cognate interactions with B cells contribute to the rapid production of antibodies directed against conserved non-protein antigens resulting in robust, but short-lived, innate humoral immunity. Later, iNKT cells can provide non-cognate help for the generation of antibodies directed against protein antigens, by promoting the maturation and activation of $\mathrm{T}_{\mathrm{FH}}$ cells, resulting in long-lasting adaptive humoral immunity and the generation of memory B cells. The ability of iNKT cells to promote innate and adaptive humoral immune responses is balanced by their ability to induce maturation of B cells into Breg cells capable of inhibiting the generation of autoantibodies and preventing autoimmune disease. Based on studies in mice, iNKT cells hold great promise as immunomodulators for the treatment of disease. A key challenge with these multifunctional cells will be to harness the protective immunity that they offer for various types of disease while suppressing pathogenic immune stimulation. Several steps have been made to fine-tune iNKT cell stimulation for the treatment of disease. Synthetic glycolipid ligands, including structural analogs of $\alpha$-GalCer, that bind to CD1d and exhibit partial agonist activity for iNKT cells can increase their therapeutic value while eliminating their pathogenic potential (138-140). Nanoparticle formulations which deliver glycolipid adjuvants 
to relevant APCs may further enhance their efficacy $(141,142)$. Tissue-specific modulation of CD1d expression, using epigenetic modifying drugs or retinoic acid, can render cells more susceptible to killing by iNKT cells $(104,143)$. The ability of iNKT cells to mediate immune protection can also be enhanced using cytokines or by antibody-mediated blocking of immune checkpoint inhibitors, such as PD-1 or cytotoxic T lymphocyte antigen-4 (144). Modification of iNKT cells to express chimeric antigen receptors (CAR-iNKT cells) or homing chemokine receptors may also prove effective for delivering the effector functions of these cells to target organs in the body (145).

\section{REFERENCES}

1. Bendelac A, Savage PB, Teyton L. The biology of NKT cells. Annu Rev Immunol (2007) 25:297-336. doi:10.1146/annurev.immunol.25.022106.141711

2. Salio M, Silk JD, Jones EY, Cerundolo V. Biology of CD1- and MR1restricted T cells. Annu Rev Immunol (2014) 32:323-66. doi:10.1146/ annurev-immunol-032713-120243

3. Marrero I, Ware R, Kumar V. Type II NKT cells in inflammation, autoimmunity, microbial immunity, and cancer. Front Immunol (2015) 6:316. doi:10.3389/fimmu.2015.00316

4. Dhodapkar MV, Kumar V. Type II NKT cells and their emerging role in health and disease. J Immunol (2017) 198:1015-21. doi:10.4049/jimmunol. 1601399

5. Brennan PJ, Tatituri RV, Brigl M, Kim EY, Tuli A, Sanderson JP, et al. Invariant natural killer $\mathrm{T}$ cells recognize lipid self antigen induced by microbial danger signals. Nat Immunol (2011) 12:1202-11. doi:10.1038/ni.2143

6. FacciottiF, RamanjaneyuluGS,LeporeM,SansanoS, CavallariM,Kistowska M, et al. Peroxisome-derived lipids are self antigens that stimulate invariant natural killer T cells in the thymus. Nat Immunol (2012) 13:474-80. doi:10.1038/ni.2245

7. Mattner J, Debord KL, Ismail N, Goff RD, Cantu C III, Zhou D, et al. Exogenous and endogenous glycolipid antigens activate NKT cells during microbial infections. Nature (2005) 434:525-9. doi:10.1038/nature03408

8. Tatituri RV, Watts GF, Bhowruth V, Barton N, Rothchild A, Hsu FF, et al. Recognition of microbial and mammalian phospholipid antigens by NKT cells with diverse TCRs. Proc Natl Acad Sci U S A (2013) 110:1827-32. doi:10.1073/pnas.1220601110

9. Kawano T, Cui J, Koezuka Y, Toura I, Kaneko Y, Motoki K, et al. CD1drestricted and TCR-mediated activation of V $\alpha 14$ NKT cells by glycosylceramides. Science (1997) 278:1626-9. doi:10.1126/science.278.5343.1626

10. Gumperz JE, Miyake S, Yamamura T, Brenner MB. Functionally distinct subsets of CD1d-restricted natural killer T cells revealed by CD1d tetramer staining. J Exp Med (2002) 195:625-36. doi:10.1084/jem.20011786

11. O’Reilly V, Zeng SG, Bricard G, Atzberger A, Hogan AE, Jackson J, et al. Distinct and overlapping effector functions of expanded human $\mathrm{CD}^{+}$, CD $8 \alpha^{+}$and CD4CD8 $\alpha^{-}$invariant natural killer T cells. PLoS One (2011) 6:e28648. doi:10.1371/journal.pone.0028648

12. Lin H, Nieda M, Rozenkov V, Nicol AJ. Analysis of the effect of different NKT cell subpopulations on the activation of CD4 and CD8 T cells, NK cells, and B cells. Exp Hematol (2006) 34:289-95. doi:10.1016/j.exphem.2005. 12.008

13. Carnaud C, Lee D, Donnars O, Park SH, Beavis A, Koezuka Y, et al. Cutting edge: cross-talk between cells of the innate immune system: NKT cells rapidly activate NK cells. J Immunol (1999) 163:4647-50.

14. Münz C, Steinman RM, Fujii S. Dendritic cell maturation by innate lymphocytes: coordinated stimulation of innate and adaptive immunity. J Exp Med (2005) 202:203-7. doi:10.1084/jem.20050810

15. Fujii S, Shimizu K, Hemmi H, Steinman RM. Innate $\mathrm{V} \alpha 14^{+}$natural killer $\mathrm{T}$ cells mature dendritic cells, leading to strong adaptive immunity. Immunol Rev (2007) 220:183-98. doi:10.1111/j.1600-065X.2007.00561.x

16. Lynch L, Michelet X, Zhang S, Brennan PJ, Moseman A, Lester C, et al. Regulatory iNKT cells lack expression of the transcription factor PLZF and control the homeostasis of $\mathrm{T}_{\mathrm{reg}}$ cells and macrophages in adipose tissue. Nat Immunol (2015) 16:85-95. doi:10.1038/ni.3047

\section{AUTHOR CONTRIBUTIONS}

All authors contributed to the conception, writing, and critical revising of this review.

\section{FUNDING}

The authors acknowledge support from Consejo Nacional de Ciencia y Tecnología (CONACyT, Mexico; to AM), the Department of Immunology, Trinity College Dublin (to AM-O) and Imcyse (Sart Tilman, Belgium; to AS).

17. Hwang SJ, Kim S, Park WS, Chung DH. IL-4-secreting NKT cells prevent hypersensitivity pneumonitis by suppressing IFN-gamma-producing neutrophils. J Immunol (2006) 177:5258-68. doi:10.4049/jimmunol.177. 8.5258

18. De Santo C, Arscott R, Booth S, Karydis I, Jones M, Asher R, et al. Invariant NKT cells modulate the suppressive activity of IL-10-secreting neutrophils differentiated with serum amyloid A. Nat Immunol (2010) 11:1039-46. doi:10.1038/ni.1942

19. De Santo C, Salio M, Masri SH, Lee LY, Dong T, Speak AO, et al. Invariant NKT cells reduce the immunosuppressive activity of influenza A virusinduced myeloid-derived suppressor cells in mice and humans. J Clin Invest (2008) 118:4036-48. doi:10.1172/JCI36264

20. An B, Lim JY, Jeong S, Shin DM, Choi EY, Min CK, et al. CD1d is a novel cell-surface marker for human monocytic myeloid-derived suppressor cells with $\mathrm{T}$ cell suppression activity in peripheral blood after allogeneic hematopoietic stem cell transplantation. Biochem Biophys Res Commun (2018) 495:519-25. doi:10.1016/j.bbrc.2017.11.010

21. Kitamura H, Iwakabe K, Yahata T, Nishimura S, Ohta A, Ohmi Y, et al. The natural killer T (NKT) cell ligand alpha-galactosylceramide demonstrates its immunopotentiating effect by inducing interleukin (IL)-12 production by dendritic cells and IL-12 receptor expression on NKT cells. J Exp Med (1999) 189:1121-8. doi:10.1084/jem.189.7.1121

22. Tomura M, Yu WG, Ahn HJ, Yamashita M, Yang YF, Ono S, et al. A novel function of $\mathrm{V} \alpha 14^{+} \mathrm{CD} 4^{+} \mathrm{NKT}$ cells: stimulation of IL-12 production by antigen-presenting cells in the innate immune system. J Immunol (1999) 163(1):93-101.

23. Vincent MS, Leslie DS, Gumperz JE, Xiong X, Grant EP, Brenner MB. CD1-dependent dendritic cell instruction. Nat Immunol (2002) 3:1163-8. doi: $10.1038 /$ ni851

24. Hogan AE, O'Reilly V, Dunne MR, Dere RT, Zeng SG, O'Brien C, et al. Activation of human invariant natural killer $\mathrm{T}$ cells with a thioglycoside analogue of $\alpha$-galactosylceramide. Clin Immunol (2011) 140:196-207. doi:10.1016/j.clim.2011.03.016

25. Fujii S, Shimizu K, Smith C, Bonifaz L, Steinman RM. Activation of natural killer $\mathrm{T}$ cells by $\alpha$-galactosylceramide rapidly induces the full maturation of dendritic cells in vivo and thereby acts as an adjuvant for combined CD4 and CD8 T cell immunity to a coadministered protein. J Exp Med (2003) 198:267-79. doi:10.1084/jem.20030324

26. Taraban VY, Martin S, Attfield KE, Glennie MJ, Elliott T, Elewaut D, et al. Invariant NKT cells promote CD8+ cytotoxic T cell responses by inducing CD70 expression on dendritic cells. J Immunol (2008) 180:4615-20. doi:10.4049/jimmunol.180.7.4615

27. Semmling V, Lukacs-Kornek V, Thaiss CA, Quast T, Hochheiser K, Panzer U, et al. Alternative cross-priming through CCL17-CCR4-mediated attraction of CTLs toward NKT cell-licensed DCs. Nat Immunol (2010) 11:313-20. doi:10.1038/ni. 1848

28. Hermans IF, Silk JD, Gileadi U, Salio M, Mathew B, Ritter G, et al. NKT cells enhance $\mathrm{CD}^{+}$and $\mathrm{CD}^{+} \mathrm{T}$ cell responses to soluble antigen in vivo through direct interaction with dendritic cells. J Immunol (2003) 171:5140-7. doi:10.4049/jimmunol.171.10.5140

29. Iwamura C, Shinoda K, Endo Y, Watanabe Y, Tumes DJ, Motohashi S, et al. Regulation of memory CD4 T-cell pool size and function by natural killer T cells in vivo. Proc Natl Acad Sci U S A (2012) 109:16992-7. doi:10.1073/ pnas. 1203494109 
30. Gottschalk C, Mettke E, Kurts C. The role of invariant natural killer T cells in dendritic cell licensing, cross-priming, and memory $\mathrm{CD}^{+} \mathrm{T}$ cell generation. Front Immunol (2015) 6:379. doi:10.3389/fimmu.2015.00379

31. Liu TY, Uemura Y, Suzuki M, Narita Y, Hirata S, Ohyama H, et al. Distinct subsets of human invariant NKT cells differentially regulate $\mathrm{T}$ helper responses via dendritic cells. Eur J Immunol (2008) 38:1012-23. doi:10.1002/ eji.200737838

32. Willard-Mack CL. Normal structure, function, and histology of lymph nodes. Toxicol Pathol (2006) 34:409-24. doi:10.1080/01926230600867727

33. Vinuesa CG, Tangye SG, Moser B, Mackay CR. Follicular B helper T cells in antibody responses and autoimmunity. Nat Rev Immunol (2005) 5:853-65. doi:10.1038/nri1714

34. McHeyzer-Williams LJ, McHeyzer-Williams MG. Antigen-specific memory B cell development. Annu Rev Immunol (2005) 23:487-513. doi:10.1146/ annurev.immunol.23.021704.115732

35. MacLennan IC, Toellner KM, Cunningham AF, Serre K, Sze DM, Zúñiga E, et al. Extrafollicular antibody responses. Immunol Rev (2003) 194:8-18. doi:10.1034/j.1600-065X.2003.00058.x

36. Klein U, Dalla-Favera R. Germinal centres: role in B-cell physiology and malignancy. Nat Rev Immunol (2008) 8:22-33. doi:10.1038/nri2217

37. Victora GD, Nussenzweig MC. Germinal centers. Annu Rev Immunol (2012) 30:429-57. doi:10.1146/annurev-immunol-020711-075032

38. Steiniger BS. Human spleen microanatomy: why mice do not suffice. Immunology (2015) 145:334-46. doi:10.1111/imm.12469

39. Crotty S. Follicular helper CD4 T cells (TFH). Annu Rev Immunol (2011) 29:621-63. doi:10.1146/annurev-immunol-031210-101400

40. Ozaki K, Spolski R, Feng CG, Qi CF, Cheng J, Sher A, et al. A critical role for IL-21 in regulating immunoglobulin production. Science (2002) 298: 1630-4. doi:10.1126/science.1077002

41. Spolski R, Leonard WJ. IL-21 and T follicular helper cells. Int Immunol (2010) 22:7-12. doi:10.1093/intimm/dxp112

42. Mond JJ, Lees A, Snapper CM. T cell-independent antigens type 2. Annu Rev Immunol (1995) 13:655-92. doi:10.1146/annurev.iy.13.040195.003255

43. Cerutti A, Cols M, Puga I. Marginal zone B cells: virtues of innate-like antibody-producing lymphocytes. Nat Rev Immunol (2013) 13:118-32. doi: $10.1038 /$ nri3383

44. Barral P, Polzella P, Bruckbauer A, van Rooijen N, Besra GS, Cerundolo V, et al. $\mathrm{CD} 169^{+}$macrophages present lipid antigens to mediate early activation of iNKT cells in lymph nodes. Nat Immunol (2010) 11:303-12. doi:10.1038/ ni. 1853

45. Barral P, Sánchez-Niño MD, van Rooijen N, Cerundolo V, Batista FD. The location of splenic NKT cells favours their rapid activation by blood-borne antigen. EMBO J (2012) 31:2378-90. doi:10.1038/emboj.2012.87

46. King IL, Amiel E, Tighe M, Mohrs K, Veerapen N, Besra G, et al. The mechanism of splenic invariant NKT cell activation dictates localization in vivo. J Immunol (2013) 191:572-82. doi:10.4049/jimmunol.1300299

47. Vomhof-DeKrey EE, Yates J, Leadbetter EA. Invariant NKT cells provide innate and adaptive help for B cells. Curr Opin Immunol (2014) 28(1):2-7. doi:10.1016/j.coi.2014.01.007

48. Gaya M, Barral P, Burbage M, Aggarwal S, Montaner B, Warren Navia A, et al. Initiation of antiviral B cell immunity relies on innate signals from spatially positioned NKT cells. Cell (2018) 172:517-33. doi:10.1016/j.cell.2017.11.036

49. Ko SY, Ko HJ, Chang WS, Park SH, Kweon MN, Kang CY. Alphagalactosylceramide can act as a nasal vaccine adjuvant inducing protective immune responses against viral infection and tumor. J Immunol (2005) 175:3309-17. doi:10.4049/jimmunol.175.5.3309

50. Lang GA, Exley MA, Lang ML. The CD1d-binding glycolipid $\alpha$-galactosylceramide enhances humoral immunity to T-dependent and T-independent antigen in a CD1d-dependent manner. Immunology (2006) 119:116-25. doi:10.1111/j.1365-2567.2006.02413.x

51. Galli G, Pittoni P, Tonti E, Malzone C, Uematsu Y, Tortoli M, et al. Invariant NKT cells sustain specific B cell responses and memory. Proc Natl Acad Sci U S A (2007) 104:3984-9. doi:10.1073/pnas.0700191104

52. Tonti E, Galli G, Malzone C, Abrignani S, Casorati G, Dellabona P. NKT-cell help to B lymphocytes can occur independently of cognate interaction. Blood (2009) 113:370-6. doi:10.1182/blood-2008-06-166249

53. Lang GA, Devera TS, Lang ML. Requirement for CD1d expression by B cells to stimulate NKT cell-enhanced antibody production. Blood (2008) 111:2158-62. doi:10.1182/blood-2007-10-117309
54. Devera TS, Shah HB, Lang GA, Lang ML. Glycolipid-activated NKT cells support the induction of persistent plasma cell responses and antibody titers. Eur J Immunol (2008) 38:1001-11. doi:10.1002/eji.200738000

55. Shah HB, Joshi SK, Rampuria P, Devera TS, Lang GA, Stohl W, et al. BAFFand APRIL-dependent maintenance of antibody titers after immunization with T-dependent antigen and CD1d-binding ligand. J Immunol (2013) 191:1154-63. doi:10.4049/jimmunol.1300263

56. Zimmerer JM, Swamy P, Sanghavi PB, Wright CL, Abdel-Rasoul M, Elzein SM, et al. Critical role of NKT cells in posttransplant alloantibody production. Am J Transplant (2014) 14:2491-9. doi:10.1111/ajt.12922

57. Barral P, Eckl-Dorna J, Harwood NE, De Santo C, Salio M, Illarionov P, et al. B cell receptor-mediated uptake of CD1d-restricted antigen augments antibody responses by recruiting invariant NKT cell help in vivo. Proc Nat Acad Sci U S A (2008) 105:8345-50. doi:10.1073/pnas.0802968105

58. Leadbetter EA, Brigl M, Illarionov P, Cohen N, Luteran MC, Pillai S, et al. NK T cells provide lipid antigen-specific cognate help for B cells. Proc Natl Acad Sci U S A (2008) 105:8339-44. doi:10.1073/pnas.0801375105

59. King IL, Fortier A, Tighe M, Dibble J, Watts GF, Veerapen N, et al. Invariant natural killer $\mathrm{T}$ cells direct $\mathrm{B}$ cell responses to cognate lipid antigen in an IL-21-dependent manner. Nat Immunol (2011) 13:44-50. doi:10.1038/ni.2172

60. Chang PP, Barral P, Fitch J, Pratama A, Ma CS, Kallies A, et al. Identification of Bcl-6-dependent follicular helper NKT cells that provide cognate help for B cell responses. Nat Immunol (2011) 13:35-43. doi:10.1038/ni.2166

61. Mattner J, Savage PB, Leung P, Oertelt SS, Wang V, Trivedi O, et al. Liver autoimmunity triggered by microbial activation of natural killer $\mathrm{T}$ cells. Cell Host Microbe (2008) 3:304-15. doi:10.1016/j.chom.2008.03.009

62. Gentilini MV, Pérez ME, Fernández PM, Fainboim L, Arana E. The tumor antigen N-glycolyl-GM3 is a human CD1d ligand capable of mediating B cell and natural killer T cell interaction. Cancer Immunol Immunother (2016) 65:551-62. doi:10.1007/s00262-016-1812-y

63. Nair S, Boddupalli CS, Verma R, Liu J, Yang R, Pastores GM, et al. Type II NKT- $\mathrm{T}_{\mathrm{FH}}$ cells against Gaucher lipids regulate B-cell immunity and inflammation. Blood (2015) 125:1256-71. doi:10.1182/blood-2014-09-600270

64. Wu C, Li Z, Fu X, Yu S, Lao S, Yang B. Antigen-specific human NKT cells from tuberculosis patients produce IL-21 to help B cells for the production of immunoglobulins. Oncotarget (2015) 6:28633-45. doi:10.18632/oncotarget.5764

65. Rampuria P, Lang GA, Devera TS, Gilmore C, Ballard JD, Lang ML. Coordination between T helper cells, iNKT cells, and their follicular helper subsets in the humoral immune response against Clostridium difficile toxin $\mathrm{B}$. J Leukoc Biol (2017) 101:567-76. doi:10.1189/jlb.4A0616-271R

66. Bai L, Deng S, Reboulet R, Mathew R, Teyton L, Savage PB, et al. Natural killer T (NKT)-B-cell interactions promote prolonged antibody responses and long-term memory to pneumococcal capsular polysaccharides. Proc Natl Acad Sci U S A (2013) 110:16097-102. doi:10.1073/pnas.1303218110

67. Chen Z, Zhu S, Wang L, Xie D, Zhang H, Li X, et al. Memory Follicular Helper Invariant NKT Cells Recognize Lipid Antigens on Memory B Cells and Elicit Antibody Recall Responses. J Immunol (2018) 200(9):3117-27. doi:10.4049/ jimmunol.1701026

68. Tonti E, Fedeli M, Napolitano A, Iannacone M, von Andrian UH, Guidotti LG, et al. Follicular helper NKT cells induce limited B cell responses and germinal center formation in the absence of $\mathrm{CD}^{+} \mathrm{T}$ cell help. J Immunol (2012) 188:3217-22. doi:10.4049/jimmunol.1103501

69. Galli G, Nuti S, Tavarini S, Galli-Stampino L, De Lalla C, Casorati G, et al. CD1d-restricted help to B cells by human invariant natural killer T lymphocytes. J Exp Med (2003) 197:1051-7. doi:10.1084/jem.20021616

70. Rossignol A, Barra A, Herbelin A, Preud'homme JL, Gombert JM. Freshly isolated $\mathrm{V} \alpha 24^{+} \mathrm{CD} 4^{+}$invariant natural killer $\mathrm{T}$ cells activated by $\alpha$-galactosylceramide-pulsed B cells promote both IgG and IgE production. Clin Exp Immunol (2007) 148:555-63. doi:10.1111/j.1365-2249.2007. 03364.x

71. Zeng SG, Ghnewa YG, O’Reilly VP, Lyons VG, Atzberger A, Hogan AE, et al. Human invariant NKT cell subsets differentially promote differentiation, antibody production, and $\mathrm{T}$ cell stimulation by $\mathrm{B}$ cells in vitro. J Immunol (2013) 191:1666-76. doi:10.4049/jimmunol.1202223

72. Rodríguez-Pinto D. B cells as antigen presenting cells. Cell Immunol (2005) 238:67-75. doi:10.1016/j.cellimm.2006.02.005

73. Harris DP, Haynes L, Sayles PC, Duso DK, Eaton SM, Lepak NM, et al. Reciprocal regulation of polarized cytokine production by effector B and T cells. Nat Immunol (2000) 1:475-82. doi:10.1038/82717 
74. Rachitskaya AV, Hansen AM, Horai R, Li Z, Villasmil R, Luger D, et al. Cutting edge: NKT cells constitutively express IL-23 receptor and ROR $\gamma \mathrm{t}$ and rapidly produce IL-17 upon receptor ligation in an IL-6-independent fashion. J Immunol (2008) 180:5167-71. doi:10.4049/jimmunol.180. 8.5167

75. Rosser EC, Mauri C. Regulatory B cells: origin, phenotype, and function. Immunity (2015) 42:607-12. doi:10.1016/j.immuni.2015.04.005

76. Yanaba K, Bouaziz JD, Haas KM, Poe JC, Fujimoto M, Tedder TF. A regulatory B cell subset with a unique $\mathrm{CD} 1 \mathrm{dhiCD} 5+$ phenotype controls $\mathrm{T}$ cell-dependent inflammatory responses. Immunity (2008) 28:639-50. doi:10.1016/j.immuni.2008.03.017

77. Yang M, Sun L, Wang S, Ko KH, Xu H, Zheng BJ, et al. Novel function of $B$ cell-activating factor in the induction of IL-10-producing regulatory B cells. J Immunol (2010) 184:3321-5. doi:10.4049/jimmunol.0902551

78. Blair PA, Noreña LY, Flores-Borja F, Rawlings DJ, Isenberg DA, Ehrenstein MR, et al. $\mathrm{CD} 19^{+} \mathrm{CD} 24^{\text {hi }} \mathrm{CD} 38^{\text {hi }} \mathrm{B}$ cells exhibit regulatory capacity in healthy individuals but are functionally impaired in systemic lupus erythematosus patients. Immunity (2010) 32:129-40. doi:10.1016/j.immuni.2009.11.009

79. Bouaziz JD, Calbo S, Maho-Vaillant M, Saussine A, Bagot M, Bensussan A, et al. IL-10 produced by activated human B cells regulates $\mathrm{CD} 4^{+} \mathrm{T}$-cell activation in vitro. Eur J Immunol (2010) 40:2686-91. doi:10.1002/eji.201040673

80. Vomhof-DeKrey EE, Yates J, Hägglöf T, Lanthier P, Amiel E, Veerapen N, et al. Cognate interaction with iNKT cells expands IL-10-producing B regulatory cells. Proc Natl Acad Sci U S A (2015) 112:12474-9. doi:10.1073/ pnas. 1504790112

81. Van Kaer L, Parekh VV, Wu L. The response of CD1d-restricted invariant NKT cells to microbial pathogens and their products. Front Immunol (2015) 6:226. doi:10.3389/fimmu.2015.00226

82. Crosby CM, Kronenberg M. Invariant natural killer T cells: front line fighters in the war against pathogenic microbes. Immunogenetics (2016) 68:639-48. doi:10.1007/s00251-016-0933-y

83. Schofield L, McConville MJ, Hansen D, Campbell AS, Fraser-Reid B, Grusby MJ, et al. CD1d-restricted immunoglobulin G formation to GPI-anchored antigens mediated by NKT cells. Science (1999) 283:225-9. doi:10.1126/ science.283.5399.225

84. Kobrynski LJ, Sousa AO, Nahmias AJ, Lee FK. Cutting edge: antibody production to pneumococcal polysaccharides requires CD1 molecules and CD8 ${ }^{+}$ T cells. J Immunol (2005) 174:1787-90. doi:10.4049/jimmunol.174.4.1787

85. Youn HJ, Ko SY, Lee KA, Ko HJ, Lee YS, Fujihashi K, et al. A single intranasal immunization with inactivated influenza virus and alpha-galactosylceramide induces long-term protective immunity without redirecting antigen to the central nervous system. Vaccine (2007) 25:5189-98. doi:10.1016/j. vaccine.2007.04.081

86. Kamijuku H, Nagata $\mathrm{Y}$, Jiang $\mathrm{X}$, Ichinohe T, Tashiro T, Mori $\mathrm{K}$, et al. Mechanism of NKT cell activation by intranasal coadministration of alphagalactosylceramide, which can induce cross-protection against influenza viruses. Mucosal Immunol (2008) 1:208-18. doi:10.1038/mi.2008.2

87. Raftery MJ, Wolter E, Fillatreau S, Meisel H, Kaufmann SH, Schönrich G. NKT cells determine titer and subtype profile of virus-specific IgG antibodies during herpes simplex virus Infection. JImmunol (2014) 192:4294-302. doi:10.4049/jimmunol.1300148

88. Devera TS, Aye LM, Lang GA, Joshi SK, Ballard JD, Lang ML. CDlddependent B-cell help by NK-like T cells leads to enhanced and sustained production of Bacillus anthracis lethal toxin-neutralizing antibodies. Infect Immun (2010) 78:1610-7. doi:10.1128/IAI.00002-10

89. Belperron AA, Dailey CM, Bockenstedt LK. Infection-induced marginal zone B cell production of Borrelia hermsii-specific antibody is impaired in the absence of CD1d. J Immunol (2005) 174:5681-6. doi:10.4049/jimmunol. 174.9.5681

90. Lisbonne M, Diem S, de Castro Keller A, Lefort J, Araujo LM, Hachem P, et al. Cutting edge: invariant $\mathrm{V}$ alpha $14 \mathrm{NKT}$ cells are required for allergeninduced airway inflammation and hyperreactivity in an experimental asthma model. J Immunol (2003) 171:1637-41. doi:10.4049/jimmunol.171.4.1637

91. Scanlon ST, Thomas SY, Ferreira CM, Bai L, Krausz T, Savage PB, et al. Airborne lipid antigens mobilize resident intravascular NKT cells to induce allergic airway inflammation. J Exp Med (2011) 208:2113-24. doi:10.1084/ jem.20110522

92. Tazawa H, Irei T, Tanaka Y, Igarashi Y, Tashiro H, Ohdan H. Blockade of invariant TCR-CD1d interaction specifically inhibits antibody production against blood group A carbohydrates. Blood (2013) 122:2582-90. doi:10.1182/ blood-2012-02-407452

93. Cui J, Shin T, Kawano T, Sato H, Kondo E, Toura I, et al. Requirement for V $\alpha 14$ NKT cells in IL-12-mediated rejection of tumors. Science (1997) 278:1623-6. doi:10.1126/science.278.5343.1623

94. Nair S, Dhodapkar MV. Natural killer T cells in cancer immunotherapy. Front Immunol (2017) 8:1178. doi:10.3389/fimmu.2017.01178

95. Metelitsa LS, Naidenko OV, Kant A, Wu HW, Loza MJ, Perussia B, et al. Human NKT cells mediate antitumor cytotoxicity directly by recognizing target cell CD1d with bound ligand or indirectly by producing IL-2 to activate NK cells. J Immunol (2001) 167:3114-22. doi:10.4049/jimmunol.167. 6.3114

96. Bassiri H, Das R, Nichols KE. Invariant NKT cells: killers and conspirators against cancer. Oncoimmunology (2013) 2:e27440. doi:10.4161/onci.27440

97. Kenna T, Golden-Mason L, Porcelli SA, Koezuka Y, Hegarty JE, O’Farrelly C, et al. NKT cells from normal and tumor-bearing human livers are phenotypically and functionally distinct from murine NKT cells. J Immunol (2003) 171:1775-9. doi:10.4049/jimmunol.171.10.5631

98. Berzins SP, Smyth MJ, Baxter AG. Presumed guilty: natural killer T cell defects and human diseases. Nat Rev Immunol (2011) 11:131-42. doi:10.1038/ nri2904

99. Chang DH, Osman K, Connolly J, Kukreja A, Krasovsky J, Pack M, et al. Sustained expansion of NKT cells and antigen-specific T cells after injection of $\alpha$-galactosyl-ceramide loaded mature dendritic cells in cancer patients. J Exp Med (2005) 201:1503-17. doi:10.1084/jem.20042592

100. Kunii N, Horiguchi S, Motohashi S, Yamamoto H, Ueno N, Yamamoto S, et al. Combination therapy of in vitro-expanded natural killer $\mathrm{T}$ cells and $\alpha$-galactosylceramide-pulsed antigen-presenting cells in patients with recurrent head and neck carcinoma. Cancer Sci (2009) 100:1092-8. doi:10.1111/ j.1349-7006.2009.01135.x

101. Caligaris-Cappio F, Hamblin TJ. B-cell chronic lymphocytic leukemia: a bird of a different feather. J Clin Oncol (1999) 17:399-408. doi:10.1200/ JCO.1999.17.1.399

102. Weinkove R, Brooks CR, Carter JM, Hermans IF, Ronchese F. Functional invariant natural killer T-cell and CD1d axis in chronic lymphocytic leukemia: implications for immunotherapy. Haematologica (2012) 98:376-84. doi:10.3324/haematol.2012.072835

103. Jadidi-Niaragh F, Jeddi-Tehrani M, Ansaripour B, Razavi SM, Sharifian RA, Shokri F. Reduced frequency of NKT-like cells in patients with progressive chronic lymphocytic leukemia. Med Oncol (2012) 29:3561-9. doi:10.1007/ s12032-012-0262-4

104. Ghnewa YG, O’Reilly VP, Vandenberghe E, Browne PV, McElligott AM, Doherty DG. Retinoic acid induction of CD1d expression primes chronic lymphocytic leukemia $\mathrm{B}$ cells for killing by $\mathrm{CD}^{+}$invariant natural killer T cells. Clin Immunol (2017) 183:91-8. doi:10.1016/j.clim.2017.08.002

105. Zheng Z, Venkatapathy S, Rao G, Harrington CA. Expression profiling of $B$ cell chronic lymphocytic leukemia suggests deficient CD1-mediated immunity, polarized cytokine response, altered adhesion and increased intracellular protein transport and processing of leukemic cells. Leukemia (2002) 16:2429-37. doi:10.1038/sj.leu.2402711

106. Fais F, Morabito F, Stelitano C, Callea V, Zanardi S, Scudeletti M, et al. CD1d is expressed on B-chronic lymphocytic leukemia cells and mediates $\alpha$-galactosylceramide presentation to natural killer $\mathrm{T}$ lymphocytes. Int J Cancer (2004) 109:402-11. doi:10.1002/ijc.11723

107. Gorini F, Azzimonti L, Delfanti G, Scarfò L, Scielzo C, Bertilaccio MT, et al. Invariant NKT cells contribute to chronic lymphocytic leukemia surveillance and prognosis. Blood (2016) 129:3440-51. doi:10.1182/ blood-2016-11-751065

108. Dhodapkar MV, Geller MD, Chang DH, Shimizu K, Fujii S, Dhodapkar KM, et al. A reversible defect in natural killer $\mathrm{T}$ cell function characterizes the progression of premalignant to malignant multiple myeloma. J Exp Med (2003) 197:1667-76. doi:10.1084/jem.20021650

109. Spanoudakis E, Hu M, Naresh K, Terpos E, Melo V, Reid A, et al. Regulation of multiple myeloma survival and progression by CD1d. Blood (2009) 113:2498-507. doi:10.1182/blood-2008-06-161281

110. Hus I, Bojarska-Junak A, Kamińska M, Dobrzyńska-Rutkowska A, Szatan K, Szymczyk A, et al. Imbalance in circulatory iNKT, Th17 and T regulatory cell frequencies in patients with B-cell non-Hodgkin's lymphoma. Oncol Lett (2017) 14:7957-64. doi:10.3892/ol.2017.7232 
111. Sbihi Z, Dossier A, Boutboul D, Galicier L, Parizot C, Emarre A, et al. iNKT and memory B-cell alterations in HHV-8 multicentric Castleman disease. Blood (2017) 129:855-65. doi:10.1182/blood-2016-06-719716

112. Wilson SB, Kent SC, Patton KT, Orban T, Jackson RA, Exley M, et al. Extreme Th1 bias of invariant V $\alpha 24 \mathrm{~J} \alpha \mathrm{Q}$ T cells in type 1 diabetes. Nature (1998) 391:177-81. doi:10.1038/34419

113. Kukreja A, Cost G, Marker L, Zhang C, Sun Z, Lin-Su K, et al. Multiple immuno-regulatory defects in type-1 diabetes. JClin Invest (2002) 109: 131-40. doi:10.1172/JCI0213605

114. Lehuen A, Lantz O, Beaudoin L, Laloux V, Carnaud C, Bendelac A, et al. Overexpression of natural killer $\mathrm{T}$ cells protects $\mathrm{V} \alpha 14-\mathrm{J} \alpha 281$ transgenic nonobese diabetic mice against diabetes. J Exp Med (1998) 188:1831-9. doi:10.1084/jem.188.10.1831

115. Falcone M, Yeung B, Tucker L, Rodriguez E, Sarvetnick N. A defect in interleukin 12-induced activation and interferon $\gamma$ secretion of peripheral natural killer $\mathrm{T}$ cells in nonobese diabetic mice suggests new pathogenic mechanisms for insulin-dependent diabetes mellitus. J Exp Med (1999) 190:963-72. doi:10.1084/jem.190.7.963

116. Beaudoin L, Laloux V, Novak J, Lucas B, Lehuen A. NKT cells inhibit the onset of diabetes by impairing the development of pathogenic $\mathrm{T}$ cells specific for pancreatic beta cells. Immunity (2002) 17:725-36. doi:10.1016/ S1074-7613(02)00473-9

117. Illés Z, Kondo T, Newcombe J, Oka N, Tabira T, Yamamura T. Differential expression of NK T cell V $\alpha 24 \mathrm{~J} \alpha \mathrm{Q}$ invariant TCR chain in the lesions of multiple sclerosis and chronic inflammatory demyelinating polyneuropathy. J Immunol (2000) 164:4375-81. doi:10.4049/jimmunol.164.8.4375

118. Araki M, Kondo T, Gumperz JE, Brenner MB, Miyake S, Yamamura T. Th2 bias of $\mathrm{CD}^{+} \mathrm{NKT}$ cells derived from multiple sclerosis in remission. Int Immunol (2003) 15:279-88. doi:10.1093/intimm/dxg029

119. Mieza MA, Itoh T, Cui JQ, Makino Y, Kawano T, Tsuchida K, et al. Selective reduction of $\mathrm{V} \alpha 14^{+} \mathrm{NK} \mathrm{T}$ cells associated with disease development in autoimmune-prone mice. J Immunol (1996) 156:4035-40.

120. Mars LT, Gautron AS, Novak J, Beaudoin L, Diana J, Liblau RS, et al. Invariant NKT cells regulate experimental autoimmune encephalomyelitis and infiltrate the central nervous system in a CD1d-independent manner. JImmunol (2008) 181:2321-9. doi:10.4049/jimmunol.181.4.2321

121. Singh AK, Wilson MT, Hong S, Olivares-Villagómez D, Du C, Stanic AK, et al. Natural killer $\mathrm{T}$ cell activation protects mice against experimental autoimmune encephalomyelitis. J Exp Med (2001) 194:1801-11. doi:10.1084/ jem.194.12.1801

122. Cho YN, Kee SJ, Lee SJ, Seo SR, Kim TJ, Lee SS, et al. Numerical and functional deficiencies of natural killer $\mathrm{T}$ cells in systemic lupus erythematosus: their deficiency related to disease activity. Rheumatology (2011) 50:1054-63. doi:10.1093/rheumatology/keq457

123. Bosma A, Abdel-Gadir A, Isenberg DA, Jury EC, Mauri C. Lipid-antigen presentation by $\mathrm{CD} 1 \mathrm{~d}^{+} \mathrm{B}$ cells is essential for the maintenance of invariant natural killer T cells. Immunity (2012) 36:477-90. doi:10.1016/j.immuni.2012.02.008

124. Lackey DE, Olefsky JM. Regulation of metabolism by the innate immune system. Nat Rev Endocrinol (2016) 12:15-28. doi:10.1038/nrendo.2015.189

125. Touch S, Clément K, André S. T cell populations and functions are altered in human obesity and type 2 diabetes. Curr Diab Rep (2017) 17:81. doi:10.1007/ s11892-017-0900-5

126. Baglaenko Y, Manion KP, Chang NH, Loh C, Lajoie G, Wither JE. Suppression of autoimmunity by $\mathrm{CD}^{+}$IL-10-producing $\mathrm{B}$ cells in lupus-prone mice. Genes Immun (2015) 16:311-20. doi:10.1038/gene.2015.17

127. Baglaenko Y, Manion KP, Chang NH, Gracey E, Loh C, Wither JE. IL-10 production is critical for sustaining the expansion of $\mathrm{CD}^{+} \mathrm{B}$ and NKT cells and restraining autoantibody production in congenic lupus-prone mice. PLoS One (2016) 11:e0150515. doi:10.1371/journal.pone.0150515

128. Yang JQ, Wen X, Kim PJ, Singh RR. Invariant NKT cells inhibit autoreactive B cells in a contact- and CD1d-dependent manner. J Immunol (2011) 186(3):1512-20. doi:10.4049/jimmunol.1002373

129. Wen X, Yang JQ, Kim PJ, Singh RR. Homeostatic regulation of marginal zone B cells by invariant natural killer T cells. PLoS One (2011) 6:e26536. doi:10.1371/journal.pone.0026536

130. Tang X, Zhang B, Jarrell JA, Price JV, Dai H, Utz PJ, et al. Ly108 expression distinguishes subsets of invariant NKT cells that help autoantibody production and secrete IL-21 from those that secrete IL-17 in lupus prone NZB/W mice. J Autoimmun (2014) 50:87-98. doi:10.1016/j.jaut.2014.01.002
131. Wermeling F, Lind SM, Jordö ED, Cardell SL, Karlsson MC. Invariant NKT cells limit activation of autoreactive CD1d-positive B cells. J Exp Med (2010) 207:943-52. doi:10.1084/jem.20091314

132. Shen L, Zhang H, Caimol M, Benike CJ, Chakravarty EF, Strober S, et al. Invariant natural killer T cells in lupus patients promote IgG and IgG autoantibody production. Eur J Immunol (2015) 45:612-23. doi:10.1002/eji.201444760

133. Gao Y, Workman S, Gadola S, Elliott T, Grimbacher B, Williams AP. Common variable immunodeficiency is associated with a functional deficiency of invariant natural killer T cells. J Allergy Clin Immunol (2014) 133:1420-8. doi:10.1016/j.jaci.2013.10.059

134. Arduini S, Dunne J, Conlon N, Feighery C, Doherty DG. Mucosal-associated invariant $\mathrm{T}$ cells are depleted and functionally altered in patients with common variable immunodeficiency. Clin Immunol (2017) 176:23-30. doi:10.1016/j.clim.2016.12.002

135. Warnatz K, Denz A, Dräger R, Braun M, Groth C, Wolff-Vorbeck G, et al. Severe deficiency of switched memory B cells (CD27+IgM-IgD-) in subgroups of patients with common variable immunodeficiency: a new approach to classify a heterogeneous disease. Blood (2002) 2002:1544-51. doi:10.1182/blood.V99.5.1544

136. Piqueras B, Lavenu-Bombled C, Galicier L, Bergeron-van der Cruyssen F, Mouthon L, Chevret S, et al. Common variable immunodeficiency patient classification based on impaired B cell memory differentiation correlates with clinical aspects. J Clin Immunol (2003) 23:385-400. doi:10.1023/A:1025373601374

137. Erazo-Borrás LV, Álvarez-Álvarez JA, Perez-Romero CA, Orrego-Arango JC, Franco-Restrepo JL, Trujillo-Vargas CM. Skewed invariant natural killer T (iNKT) cells, impaired iNKT:B cell help and decreased SAP expression in blood lymphocytes from patients with common variable immunodeficiency. Scand J Immunol (2017) 86:171-8. doi:10.1111/sji.12576

138. Miyamoto K, Miyake S, Yamamura T. A synthetic glycolipid prevents autoimmune encephalomyelitis by inducing TH2 bias of natural killer T cells. Nature (2001) 413:531-4. doi:10.1038/35097097

139. Schmieg J, Yang G, Franck RW, Tsuji M. Superior protection against malaria and melanoma metastases by a C-glycoside analogue of the natural killer T cell ligand $\alpha$-galactosylceramide. J Exp Med (2003) 198:1631-41. doi:10.1084/jem.20031192

140. Melo AM, Zhang L, Dockry ÉF, Petrasca A, Ghnewa YG, Breen EP, et al. Novel thioglycoside analogs of $\alpha$-galactosylceramide stimulate cytotoxicity and preferential Th1 cytokine production by human invariant natural killer T cells. Glycobiology (2018) 2018:6. doi:10.1093/glycob/cwy035

141. Macho-Fernandez E, Cruz LJ, Ghinnagow R, Fontaine J, Bialecki E, Frisch B, et al. Targeted delivery of $\alpha$-galactosylceramide to $\mathrm{CD} 8 \alpha^{+}$dendritic cells optimizes type I NKT cell-based antitumor responses. J Immunol (2014) 193:961-9. doi:10.4049/jimmunol.1303029

142. Dölen Y, Kreutz M, Gileadi U, Tel J, Vasaturo A, van Dinther EA, et al. Co-delivery of PLGA encapsulated invariant NKT cell agonist with antigenic protein induce strong $\mathrm{T}$ cell-mediated antitumor immune responses. Oncoimmunology (2015) 5:e1068493. doi:10.1080/2162402X.2015.1068493

143. Dockry É, O’Leary S, Gleeson LE, Lyons J, Keane J, Gray SG, et al. Epigenetic induction of CD1d expression primes lung cancer cells for killing by invariant natural killer T cells. Oncoimmunology (2018) 7:e1428156. doi:10.1080/ 2162402X.2018.1428156

144. Kamata T, Suzuki A, Mise N, Ihara F, Takami M, Makita Y, et al. Blockade of programmed death-1/programmed death ligand pathway enhances the antitumor immunity of human invariant natural killer T cells. Cancer Immunol Immunother (2016) 65:1477-89. doi:10.1007/s00262-016-1901-y

145. Wolf BJ, Choi JE, Exley MA. Novel approaches to exploiting invariant NKT cells in cancer immunotherapy. Front Immunol (2018) 9:384. doi:10.3389/fimmu.2018.00384

Conflict of Interest Statement: The authors declare that the research was conducted in the absence of any commercial or financial relationships that could be construed as a potential conflict of interest.

Copyright (ㄷ) 2018 Doherty, Melo, Moreno-Olivera and Solomos. This is an open-access article distributed under the terms of the Creative Commons Attribution License (CC BY). The use, distribution or reproduction in other forums is permitted, provided the original author(s) and the copyright owner are credited and that the original publication in this journal is cited, in accordance with accepted academic practice. No use, distribution or reproduction is permitted which does not comply with these terms. 